\title{
A predictive numerical model for potential mapping of the gas hydrate stability zone in the Gulf of Cadiz
}

\author{
R. León ${ }^{\mathrm{a}, *}$, L. Somoza ${ }^{\mathrm{a}}$, C.J. Giménez-Moreno ${ }^{\mathrm{b}}$, C.J. Dabrio ${ }^{\mathrm{b}}$, G. Ercilla ${ }^{\mathrm{c}}$, D. Praeg ${ }^{\mathrm{d}}$, V. Díaz-del-Río ${ }^{\mathrm{e}}$, \\ M. Gómez-Delgado ${ }^{\mathrm{f}}$ \\ ${ }^{a}$ Marine Geology Division, Geological Survey of Spain IGME, Rios Rosas 23, 28003 Madrid, Spain \\ ${ }^{\mathrm{b}}$ Facultad de Ciencias Geológicas, Universidad Complutense, José Antonio Novais 2, 28040 Madrid, Spain \\ ${ }^{c}$ Instituto de Ciencias del Mar UCM-CSIC, Paseo Marítimo de la Barceloneta 37-49, 08003 Barcelona, Spain \\ ${ }^{d}$ Instituto Nazionale di Oceanografia e di Geofisica Sperimentale, Borgo Grotta Gigante 42/C, 34010 Sgonico, Trieste, Italy \\ 'Instituto Español de Oceanografía IEO, Fuengirola, 29640 Málaga, Spain \\ 'Universidad de Alcalá de Henares, C/Colegios, 2, 28801 Alcalá de Henares, Madrid, Spain
}

Keywords:

Gas hydrates

GIS

Heat flow

Fluid flow

Mud volcanoes

Gulf of Cadiz

\begin{abstract}
A B S T R A C T
This paper presents a computational model for mapping the regional 3D distribution in which seafloor gas hydrates would be stable, that is carried out in a Geographical Information System (GIS) environment. The construction of the model is comprised of three primary steps, namely: (1) the construction of surfaces for the various variables based on available 3D data (seafloor temperature, geothermal gradient and depth-pressure); (2) the calculation of the gas function equilibrium functions for the various hydrocarbon compositions reported from hydrate and sediment samples; and (3) the calculation of the thickness of the hydrate stability zone. The solution is based on a transcendental function, which is solved iteratively in a GIS environment.

The model has been applied in the northernmost continental slope of the Gulf of Cadiz, an area where an abundant supply for hydrate formation, such as extensive hydrocarbon seeps, diapirs and fault structures, is combined with deep undercurrents and a complex seafloor morphology. In the Gulf of Cadiz, the model depicts the distribution of the base of the gas hydrate stability zone for both biogenic and thermogenic gas compositions, and explains the geometry and distribution of geological structures derived from gas venting in the Tasyo Field (Gulf of Cadiz) and the generation of BSR levels on the upper continental slope.
\end{abstract}

\section{Introduction}

Gas hydrates are crystalline solids formed from water and hydrocarbon gases under low temperature and high pressure conditions. They are common world-wide in sediments of continental margins at water depths exceeding $300 \mathrm{~m}$. Although controversial, an indirect seismic indicator of the base of the gas hydrate stability zone (GHSZ) is the bottom simulating reflector (BSR) (Miller et al., 1991), which has a high amplitude and reverse polarity, and is located below a seismic "blanking" facies (Andreassen et al., 1995). The importance of evaluating the hydrate stability field on seafloors lies in the fact that the massive dissociation of hydrates generates major slumps and pockmarks inducing geological risks (Campbell, 1991; Bagirov and Lerche, 1998; Bouriak et al., 2000).

\footnotetext{
* Corresponding author.

E-mail address: r.leon@igme.es (R León).
}

A large number of pockmark-like structures (Baraza and Ercilla, 1996; Somoza et al., 2000, 2003; León et al., 2001, 2006), mud volcanoes bearing gas hydrates (Ivanov et al., 2000; Somoza et al., 2000, 2003; Standnitskaia et al., 2001; Mazurenko et al., 2002), and authigenic carbonate crusts and slabs have been reported along the continental slope (Díaz-del-Río et al., 2003; Magalhães et al., 2004; Mata et al., 2005) and have revealed the intense activity of hydrocarbon seeps in the Gulf of Cadiz on both the Iberian and African margins (Ivanov et al., 2000; Somoza et al., 2000; Gardner, 2001). These hydrocarbon seepage structures are especially frequent in an area named the Tasyo Field (Somoza et al., 2003), which is warmed by the Mediterranean outflow water (MOW). BSR levels have also been detected below the upper continental slope (Somoza et al., 2000; Casas et al., 2003; Depreiter et al., 2005).

Several quantitative models can be found in the literature for calculating the hydrate stability field in the seafloor. They calculate the theoretical hydrate stability field from equations deduced from 
its composition and infer their results from physical characteristics obtained from geophysical surveys. One of these types of models, transient models, are based on the conservation of energy (Sloan, 1998; Mienert et al., 2001, 2005; Sultan et al., 2004). Transient models are often conceptually simpler and easier to model the GHSZ 3D occurrence below seafloor as the only equation that they need to solve is that of energy conservation in transient regime. They consider the GHSZ as a function of temperature and pressure, and some of them take into account changes in oceanographic conditions that show rises and falls in the GHSZ related to changes in sea level or bottom water temperature (e.g. Vogt and Jung, 2002; Sultan et al., 2004; Mienert et al., 2005).

The regional and wide-extend 3D prospecting of the GHSZ, by the above models and methodologies, entails the difficulty of the punctual solving the GHSZ thickness and infer the results over a wide-extend area. The use of gridded datasets of the physical parameters controlling the formation of gas hydrate is a useful solution for the GHSZ 3D prospecting in several continental margins; Europe (Miles, 1995), India where there is applied an implementation of a C-program (Rao, 1999), and China Sea (Wang et al., 2006). Nevertheless, incorporation of new parameter for the system, spatial variability of parameters, actualization of new data in real time, simulation of conditions, and assessment of the uncertainty of the model and propagation error of the parameters due to algebra processes of the gridded dataset, entails an added difficulty not easy solution. This paper proposes a methodology inside a GIS environment that provides a useful solution to the difficulties above mentioned. Proposed model presents an added value to the geographical application of transient models of the hydrate stability field, managing of 3D dynamic variables such as seafloor temperature and the geothermal gradient, and introducing the gas hydrocarbon composition in the model as a boundary of the hydrate nucleation in the sub-seafloor. These parameters can be especially important in controlling the distribution of hydrates in areas with variable seawater temperatures caused by deep water undercurrents, such as the loop current of the Gulf of Mexico (Milkov and Sassen, 2001), the Mediterranean outflow undercurrent in the Gulf of Cadiz (Gardner et al., 2001) and the Congo continental slope (Sultan et al., 2004). Furthermore, the spatial variation in the sub-seafloor temperature gradient is a key control of the thickness of the GHSZ, especially in areas with anomalous heat flows related to focused fluid venting such as mud volcanoes or carbonate mounds. In addition, GIS technology allows large 3D data sets to be managed by a logical and mathematical function for solving geographical problems.

This paper presents a predictive numerical model for regional mapping of the thickness of the GHSZ. The principal contribution of this model are: (a) the understanding of the hydrocarbon gas composition as a mathematical function and the variables that control the hydrate nucleation as inferred surfaces for the estimation of the GHSZ 3D thickness; (b) the solution of the GHSZ 3D thickness based on a transcendental function, which is solved iteratively in a GIS environment; and (c) implementation of the uncertainty assessment and propagation error in the work processes of the model. The $3 \mathrm{D}$ geographical solution of the GHSZ establishes a GIS methodology for the 3D spatial inference of hydrates by incorporating real data such as bottom seawater temperatures, swath bathymetry, geothermal gradient values and hydrocarbon composition.

Furthermore, to validate this model, an area of the Gulf of Cadiz (Fig. 1) was selected as a case study. The Gulf of Cadiz is an area with a complex regime of cold and warm underwater currents, fluid flow and thermal anomalies, which control the hydrate stability field. The model explains the distributions and geometry of several geological structures related to gas venting in the Gulf of Cadiz and the presence of BSR levels on the upper continental slope of the
Gulf of Cadiz. It is also applicable to other, simpler areas such as passive continental margins.

\section{Regional setting}

The Gulf of Cadiz is the western approach to the Strait of Gibraltar, where the interchange of Atlantic and Mediterranean waters takes place (Lacombe and Lizeray, 1959). Here the Mediterranean outflow water (MOW), ranging from $12.5^{\circ} \mathrm{C}$ to $14^{\circ} \mathrm{C}$, flows below the North Atlantic surficial water (NASW) warming the seafloor in the process (Ochoa and Bray, 1991). The circulation pattern of the MOW is very complex: the Coriolis effect pushes it to the NW on the upper slope and the MOW becomes separated into several branches that move along submarine canyons and channels of the middle and upper continental slope (Hernández-Molina et al., 2003). At 900-1000 m depth, the MOW rises off the bottom and moves toward Cape San Vicente, intercalated between the North Atlantic deep water (NADW), ranging from $3{ }^{\circ} \mathrm{C}$ to $8^{\circ} \mathrm{C}$, and the North Atlantic central water (NACW), ranging from $12^{\circ} \mathrm{C}$ to $16^{\circ} \mathrm{C}$ (Ochoa and Bray, 1991) (Fig. 1).

Geologically, the Gulf of Cadiz is located at the westward front of the Betic-Rifian Arc, in the easternmost sector of the AzoresGibraltar segment of the Africa/Eurasia collisional plate boundary (Dewey et al., 1989) (Fig. 1). It has a complex geological history and has undergone several episodes of rifting, compression and strikeslip motion since the Triassic (Maldonado et al., 1999). In late Tortonian times (11.2-7.1 Ma), westward migration of the Alboran domain associated with the formation of the Betic-Rifian Arc forced the emplacement of a large sedimentary body in the Gulf of Cadiz (e.g. Bonnin et al., 1975). During the final stages of accretion of the Betic-Rifian Arc and the emplacement of thrusting units, gravitational sliding of mobile shale and salt stocks formed a giant complex of mass-wasting deposits, generally known as the Guadalquivir allochthonous unit (GAU) (Medialdea et al., 2004), which reached as far west as the Horseshoe and Seine abyssal plains (Fig. 1). This feature appears in seismic sections as a chaotic, highly diffractive body with high amplitude reflections, consisting of a mixture of Triassic, Cretaceous, Paleogene and Neogene sedimentary units overlying the Palaeozoic basement (Maldonado et al., 1999). The GAU is responsible for diapirism of huge volumes of mud and salt of Triassic units and under-compacted Early-Middle Miocene plastic marls (Maldonado et al., 1999; Medialdea et al., 2004).

Throughout this area, widespread venting of hydrocarbon-rich fluid and mud diapirism are observed as numerous mud volcanoes (e.g. Gardner, 2001; Ivanov et al., 2000; Somoza et al., 2002; Van Rensbergen et al., 2005), carbonate mounds and ridges (Díaz-delRío et al., 2003), and pockmarks (Baraza and Ercilla, 1996) (Figs. 1 and 2). These are related to the lateral compression from the AfricaEurasia convergence, which promotes migration of fluid to the surface. In the NE sector of the Gulf of Cadiz, several NE-SW oriented diapiric mud ridges occur, topped by carbonate chimneys and crusts (Díaz-del-Río et al., 2003; Somoza et al., 2003; Fernández-Puga, 2004). Gas hydrates have been sampled in mud volcanoes (Mazurenko et al., 2002; Pinheiro et al., 2003) and have been detected geophysically as BSR-like reflectors (Casas et al., 2003; Depreiter et al., 2005) (Fig. 1). Hydrates and hydrocarbon gases sampled from mud volcano sediments include both biogenic and thermogenic components (Blinova and Stadnitskaia, 2001; Mazurenko et al., 2003; Stadniskaia et al., 2006).

\section{Predictive model of the gas hydrate stability zone}

\subsection{Proposed model}

Natural gases in marine sediments result from thermogenic or biogenic formation within the seabed soil (Davie and Buffett, 2003). 


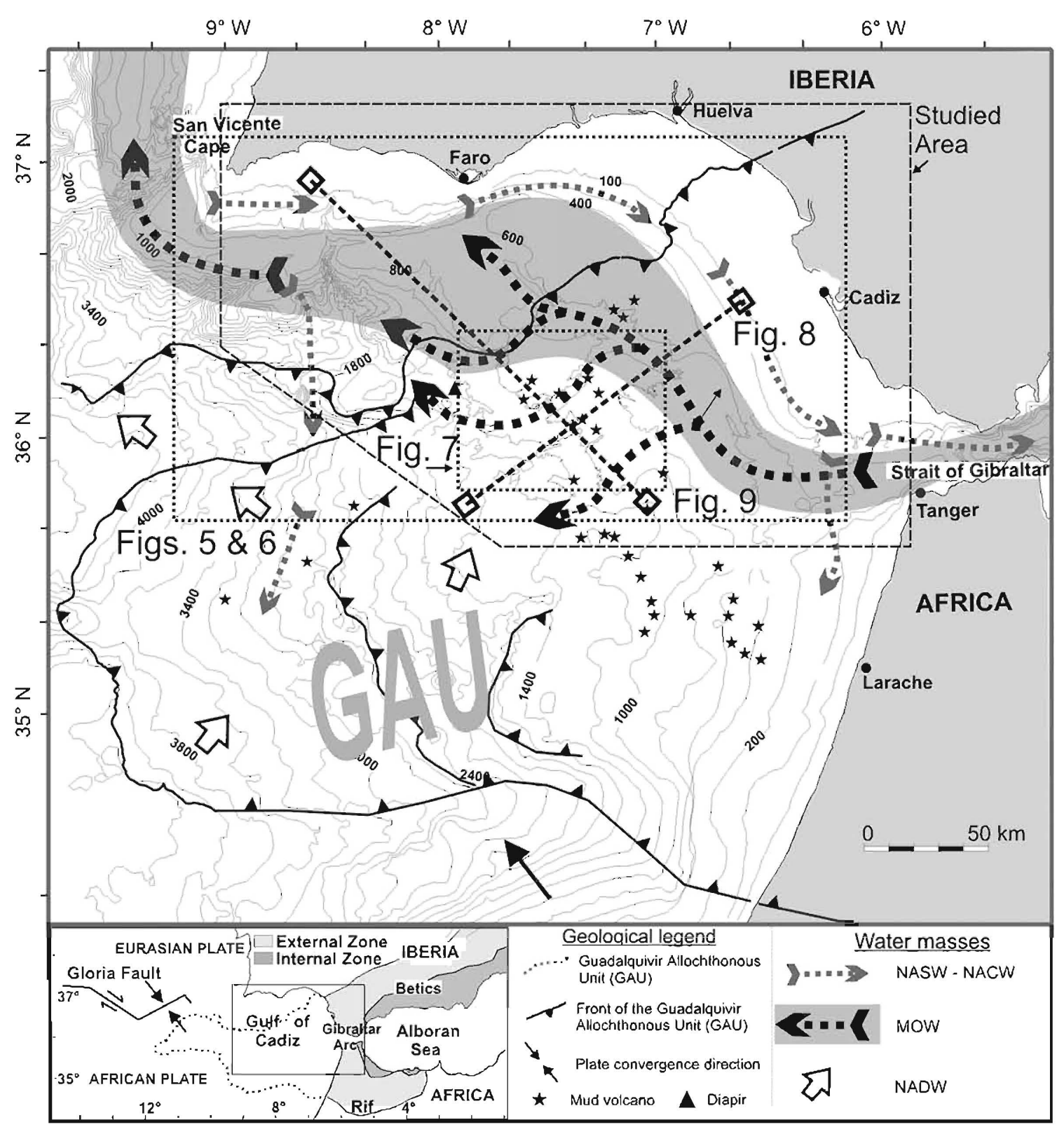

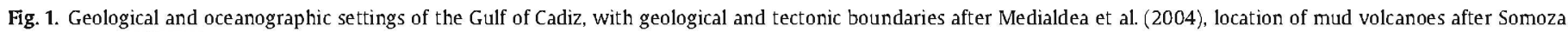
et al. (2003), Pinheiro et al. (2003) and Van Rensbergen et al. (2005), and oceanographic setting partially modified from Hernandez-Molina et al. (2003).

Under suitable temperature, salinity and pressure conditions (inside GHSZ), methane hydrates may only crystallize from natural gases when gas concentrations exceed the methane solubility in the sediment pore water (Sloan, 1998; Davie and Buffett, 2001). The base of the GHSZ is controlled by the geothermal gradient (Claypool and Kaplan, 1974; Kvenvolden, 1988, 1995). The base of the stability zone is defined by the intersection of the geothermal gradient function and the fixed function $T=f(D) \quad(T=$ temperature, $D=$ depth) for a given hydrate composition of the hydrate stability field (Fig. 3B).

The predictive numerical model allows real time actualization of the hydrate nucleation variables (temperature, pressure/depth, and geothermal gradient) because they are implemented in a GIS work process. These variables are built as inferred 3D surfaces from tabular data stored in the GIS database. The composition of gas hydrates is a function $(T=f[P])$ fixed from the hydrate stability field calculated by the statistical thermodynamic method of Sloan (1998) (Fig. 3A).
The model is built on five differentiated GIS work processes. The first steps are the construction of hydrate nucleation variables (temperature, pressure and geothermal gradient) as inferred 3D surfaces in three work processes (Figs. $4 A-C$ ). The next step is to estimate the fixed function $T=f[D]$, the hydrate stability function (HSF), for each type of hydrocarbon composition recovered (Fig. 4D). The final step is to calculate the base of the hydrate stability zone from the GIS work processes (3D surfaces and HSF) mentioned above (Fig. 4E).

\subsection{Bathymetric surface: digital bathymetric model (DBM)}

The bathymetric variable is put inside the GIS as a digital bathymetric surface. In this step we have built two bathymetric surfaces that respond to two different needs: (a) a high resolution DBM, not covering all the studied area, from swath bathymetric data (SBDM) used for accurate calculations (such as detailed GHSZ thickness calculation for slope gravitational stability hazards or an 
the GAP cruise in December 2003 (Grevemeyer et al., 2004; Kopf et al., 2004), plus geothermal data from the Repsol oil company's Neptuno-2 well (IGME, 1987) were used to construct the grid (Fig. 2). Although the geographical distribution of records is somewhat irregular and heterogeneous (Fig. 2), the information gathered is ground truth. Therefore, it was considered suitable for interpolating a numerical geothermal gradient surface.

The DGGM was built in two phases. The first step was to generate a numerical surface of the regional geothermal gradient trends (RGTS). A smooth trending surface was fixed to 51 records with a stochastic method. An ordinary kriging method has been selected with spherical model type of variogram, in which we have applied a smoothing by global polynomial interpolation method of power of one, with a maximum smoothing factor equal to one in $98,846 \mathrm{~m}$ in search radius (Fig. $6 \mathrm{~B}$ ). In the second step, the positive anomalies of the mud volcanoes were incorporated into the RGTS (Fig. 6B). More than 40 investigated mud volcanoes show elevated geothermal gradients indicating active focused fluid flow. The locations of high heat flow values are shown in Fig. 2. The mean geothermal gradient value of each mud volcano was integrated as a mask inside the RGTS.

The geothermal gradient pattern consists of a regional trend and positive and negative local anomalies. Values of the regional trend are $24-26^{\circ} \mathrm{C} \mathrm{km}^{-1}$ for the continental shelf and $39-43^{\circ} \mathrm{C} \mathrm{km}^{-1}$ for the deep abyssal plain (Fig. 6B). Theses values are consistent with the results of the thermal structure of the Gulf of Cadiz (Grevemeyer et al., 2004). Positive anomalies $\sim 50^{\circ} \mathrm{C} \mathrm{km}^{-1}$ with peak values of $98{ }^{\circ} \mathrm{C} \mathrm{km}^{-1}$ found on the continental slope are related to areas of focused fluid flow such as mud volcanoes (Gardner et al., 2001). The locations of high heat flow values are shown in Figs. 2 and 6. Otherwise, highly negative anomalies ranging from $0.16{ }^{\circ} \mathrm{C}$ $\mathrm{km}^{-1}$ to $1.5^{\circ} \mathrm{C} \mathrm{km}^{-1}$ are interpreted either as the effects of warm MOW seawater (Gardner et al., 2001) or as latent heat of hydrate dissociation processes during the deployment of heat probes (Kopf et al., 2004). We have excluded these negative anomalies because these perturbations affect only the first $2 \mathrm{~m}$ of sediment, and do not interfere in the regional geothermal gradient surface.

\subsection{Hydrate stability functions for different gas compositions}

The aim of this GIS work process is to build a function (T=f[D]) that will define the hydrate stability field relating temperature and pressure for a given composition. The phase equilibrium curves for crystallization of gas hydrates from different gas sources were calculated based on Sloan's (1998) CSMHYD program. The composition data come from Repsol's Neptune-2 oil well drilled in 1983 (IGME, 1987) and three gravity cores recovered during TTR cruises (Stadnitskaia et al., 2000). From the Neptuno-2 oil well two gas compositions were extracted, which we have called Neptuno2a and Neptuno-2c. Neptuno-2a are the traces of methane obtained at 850 mbsf and Neptuno-c are the traces of thermal gases obtained at 1770 mbsf composed of $92 \% C_{1}, 3 \% C_{2}, 1.8 \% C_{3}$ and $1.4 \% C_{4}$. The gas hydrocarbon composition $\left(C_{1}-C_{5}\right)$ was measured during the scientific TTR- 9 cruise in cores AT-201G, AT-203G and AT-208G by chromatographic analysis (Stadnitskaia et al., 2000). AT-203G (Yuma mud volcano) and AT-208G (Ginsburg mud volcano) contained allochthonous thermogenic gas, whereas AT-201G (pelagic sediments) contained autochthonous gas of microbiologic origin (biogenic) (Stadnitskaia et al., 2000, 2001, 2006; Blinova and Stadnitskaia, 2001; Mazurenko et al., 2003).

We give the name hydrate stability function (HSF) to the result of fixing a function $[T=f(D)]$ to the cloud point (T-D or temperature-pressure/depth) resulting from applying the statistical thermodynamic method (Sloan, 1998) for each gas composition. The HSF defines theoretical hydrated areas of the seafloor by means of an exponential or logarithmic fix, as the behavior of the hydrate stability field follows this type of function (Katz et al., 1959; Sloan, 1998; Milkov et al., 2000; Milkov and Sassen, 2001; Sultan, et al., 2004).

Assuming a mean salinity of $36 \%$ (the mean of Atlantic and Mediterranean salinity in the Gulf of Cadiz) in the sediment pore water, we calculated a total of six hydrate functions (one for each composition) (Fig. 3A) that can be grouped into two main clusters (Stadnitskaia et al., 2000): (a) Neptuno-2a and AT-201G with biogenic-type gases; and (b) Yuma/AT-203G, Ginsburg/AT-208G and Neptuno-2c with thermogenic-type gases (Fig. 3A).

The biogenic-type group is characterized by high concentrations of methane and unsaturated hydrocarbon gases that probably reveal active microbiological processes in the sediment (Stadnitskaia et al., 2000), as it shows similar hydrate functions (Fig. 3A). The thermogenic-type group has very high concentrations of saturated hydrocarbon gases, particularly ethane through normal pentane $\left(C_{2}-C_{5}\right)$, and also a high content of $C_{4}$ and $C_{5}$ (Stadnitskaia et al., 2000; Kozlova et al., 2000; Blinova and Stadnitskaia, 2001; Mazurenko et al., 2002). The HSF of this group cover a broader spectrum (Fig. 3A). Thus, the different behavior (shift to higher temperature values) of the HSF in Yuma/AT-203G could be probably related, as pointed out by Stadnitskaia et al. (2006), to contamination by other hydrocarbons with a different degree of maturation during its migration.

In order to simulate the hydrate stability field inside a GIS, we have fixed two logarithmic HSF for each of the two groups identified (Fig. 3A):

(a) For biogenic gases, with a determination coefficient $R$ squared $=0.998112$ :

$T=\frac{\ln D-5.2398}{0.12061}$

(Function I)

(b) For thermogenic gases, with a determination coefficient $R$ squared $=0.989278$ :

$T=\frac{\ln D-4.171846}{0.139077}$

(Function II)

where:

$D=$ depth in meters, and
$T=$ temperature in $^{\circ} \mathrm{C}$.

For the calculation of the GHSZ thickness, because the hydrate stability field always follows a logarithmic behavior, we have generated Function III, a generic form of Functions I and II. $K_{\mathrm{a}}$ and $K_{\mathrm{b}}$ are the constants resulting from fixing a function $[T=f(D)]$ to the cloud point ( $T-D$ or temperature-pressure/depth) resulting from applying the statistical thermodynamic method (Sloan, 1998) for each gas composition, $K_{\mathrm{a}}$ is the constant of the numerator of the HSF, and $K_{b}$ is the constant of the denominator of the HSF. In the present paper, $K_{\mathrm{a}}$ is equal to 5.2398 and 4.171846 for biogenic and thermogenic gas, respectively, and $K_{\mathrm{b}}$ is equal to 0.12061 and 0.139077 for biogenic and thermogenic gas, respectively.

$T=\frac{\ln D-K_{\mathrm{a}}}{K_{\mathrm{b}}}$

(Function III)

\subsection{GIS calculation of the GHSZ thickness}

Under ideal sediment pore saturation conditions, hydrocarbon gases are hydrated if environmental $P-T$ conditions fall within the hydrate stability field (Fig. 3B). Thus, seafloor hydrates are stable when the temperature at the seafloor is lower than the 
temperature calculated for the HSF, or in GIS terminology, lower than the result of reclassifying the DBM with the hydrate Functions I or II. So, generate a derived temperature surface applying HSF to the DBM. Following this reasoning, the first step was to apply the HSF of the different hydrocarbon compositions to the DBM, and to obtain two new digital temperature models depicting the theoretical seafloor temperatures under which gas-hydrates are stable. The theoretical areas where seafloor hydrates are stable are obtained by comparing these theoretical models with the one generated above for real seafloor temperatures (DBWTM). We solve this, doing a simple map algebra analysis, separating those pixels of the digital model of real seafloor temperatures whose values are lower than or equal to the equivalent pixels of the reclassified temperature model. These pixels define the areas of the seafloor where gas hydrates could occur because their formation would be stable.

Owing to the increasing temperature in the sub-seafloor, there are temperature values ( $T_{\mathrm{GHSZ}}$ ) at a depth $\left(D_{\mathrm{GHSZ}}\right)$ at which gas hydrates are no longer stable. These define the sediment/hydrate sediment/gas interface (Fig. 3B). Therefore, the depth of the hydrate stability zone ( $D_{\text {GHSZ }}$ ) is regulated by Functions III and IV (Fig. 3):

(a) The geothermal gradient function that relates the increment of sub-seafloor temperature to depth:

$T_{\mathrm{GHSZ}}=T_{\text {Seafloor }}+\left(D_{\mathrm{GHSZ}}-D_{\text {Seafloor }}\right) \delta_{g}$

(Function IV)

Where:

$D_{\mathrm{GHSZ}}=$ depth of the base of the GHSZ.

$D_{\text {Seafloor }}=$ seafloor depth.

$T_{\mathrm{GHSZ}}=$ temperature at the base of the GHSZ.

$T_{\text {Seafloor }}=$ temperature on the seafloor.

$\delta_{\mathrm{g}}=$ geothermal gradient.

(b) The generic form of the HSF that relates pressure and temperature for gas hydrates (Function III) applied in the base of the GHSZ:

$T_{\mathrm{HSZ}}=\left(\ln D_{\mathrm{HSZ}}-K_{\mathrm{a}}\right) / K_{\mathrm{b}}$

(Function V)

Assuming that sediment pores are connected to prevent overpressure, then the pore pressure equals the hydrostatic pressure. As a result of the two above Functions IV and V, the depth of base of the GHSZ $\left(D_{\text {GHSZ }}\right)$ is calculated by a transcendental Function VI that has no real solution (Fig. 3C):

Ln $D_{\mathrm{GHSZ}}=\left\{\left[T_{\text {Seafloor }}+\left(D_{\mathrm{GHSZ}}-D_{\text {Seafloor }}\right) \delta_{\mathrm{g}}\right] \mathrm{K}_{\mathrm{b}}\right\}+K_{\mathrm{a}}$

(Function VI)

As the hydrate stability field follows a logarithmic behavior, the calculation of the base of hydrate stability requires a transcendental function. In this work this transcendental function has been solved by means of the GIS with the following iterative loop for each pixel of the problem area:

Do for each pixel

GHSZ-Dpth = DBM value

auxiliary variable, aux $=$ DBM value

If (ln GHSZ-Dpth $<=\left((\right.$ DBWTM $+($ aux - DBM $) *$ DGGM $\left.) * K_{b}\right)$

$+K_{\mathrm{a}}$ ) then

GHSZ-Thickness pixel value $=$ NO DATA

else

Start loop:

Do until (In GHSZ-Dpth $<=(($ DBWTM $+($ aux - DBM $) *$ DGGM) $\left.\left.* K_{\mathrm{b}}\right)+K_{\mathrm{a}}\right)$ aux: $=(\operatorname{aux}+1)$

GHSZ-Dpth pixel value $=$ aux

End loop.

GHSZ-Thickness pixel value $=$ GHSZ-Dpth - DBM

Next pixel

Two different variables (GHSZ-Dpth and aux) have been established in order to substitute the value of the burial depth of the base of GHSZ at both sides of the transcendental function. In a first stage GHSZ-Dpth and aux are equaled to the bathymetry. At seafloor sites where hydrates are no stable, the burial depth of the base of the GHSZ will be equal to the bathymetry. Thus, the right term of the equation will be greater or equal than the left side. In this case it will have no sense to solve the equation so the pixel representing the modelization of the thickness of the hydrate stability field will be accounted for (considered) as "no data". On the other hand, when the seafloor lies within the stability field, the value of the left term of the equation will always be greater than the right one. In this case we would get into a loop where we will raise the value of the auxiliary variable (aux) to converge when the right term would be greater or equal than the left one. This convergence will always be assured. Within this loop GHSZ-Dpth will take the value of the count of aux and finally when the loop converges it will take the value of the pixel of the GHSZ thickness as the subtraction of GHSZDpth minus bathymetry.

The algorithm of the resolution of Function VII is relatively fast as the only operations to be made are the resolution of the logarithmic function and ten increase of a counter. The counter increase has been established in $2 \mathrm{~m}$, which is the maximum precision of the multibeam bathymetry data. As the thickness of the GHSZ is usually around $220-400 \mathrm{~m}$, and very rarely, up to $1.000 \mathrm{~m}$, the usual number of iterations lies within 100 and 200 . The application of this algorithm in numerical surfaces of 1666 columns and 1243 rows never exceeds $2 \mathrm{~min}$. Nevertheless the convergence speed/rate can be much greater as the bathymetric precision in the most part of the test site is $\pm 20 \mathrm{~m}$. A numerical surface is generated as a result of applying this loop in each of the test sites pixels.

As a result of applying this loop in each of the test sites pixels, a numerical surface is generated depicting the thickness of the hydrate stability zone of biogenic and thermogenic-type hydrocarbon gases (Figs. 6C,D).

\section{Application to the Gulf of Cadiz continental slope}

Several quantitative models for calculating the thickness of the GHSZ have been developed and applied in different regions characterized by extensive hydrocarbon seeps such as the Gulf of Mexico (Milkov and Sassen, 2001), the Norwegian margin (Mienert et al., 2001, 2005; Bouriak et al., 2000; Hovland and Svensen, 2006; Ivanov et al., 2007), the Nankai Trench (Fehn et al., 2003), the Blake Ridge (Tréhu et al., 2004) and the South China Sea (Wang et al., 2006). Most of these models do not consider the changes of bottom seawater related to deep undercurrents or the local spatial variability in thermal gradients associated with fluid flow along faults connected to seafloor structures such as diapirs and mud volcanoes. Only, some models, such as Vogt and Jung (2002), Sultan et al. (2004) and Mienert et al. (2005), take into account changes in oceanographic conditions that show rises and falls in the GHSZ related to changes in sea level or bottom seawater temperature.

The predictive numerical model of the GHSZ presented in this paper has been tested against the available morphological and seismic data of an area between the Guadalquivir Bank and the Tasyo field (Díaz-del-Río et al., 2003; Somoza et al., 2003). This area (Fig. 7) is characterized by two NE-SW trending diapiric ridges (Guadalquivir and Cadiz) that control the orientation of the Cadiz 


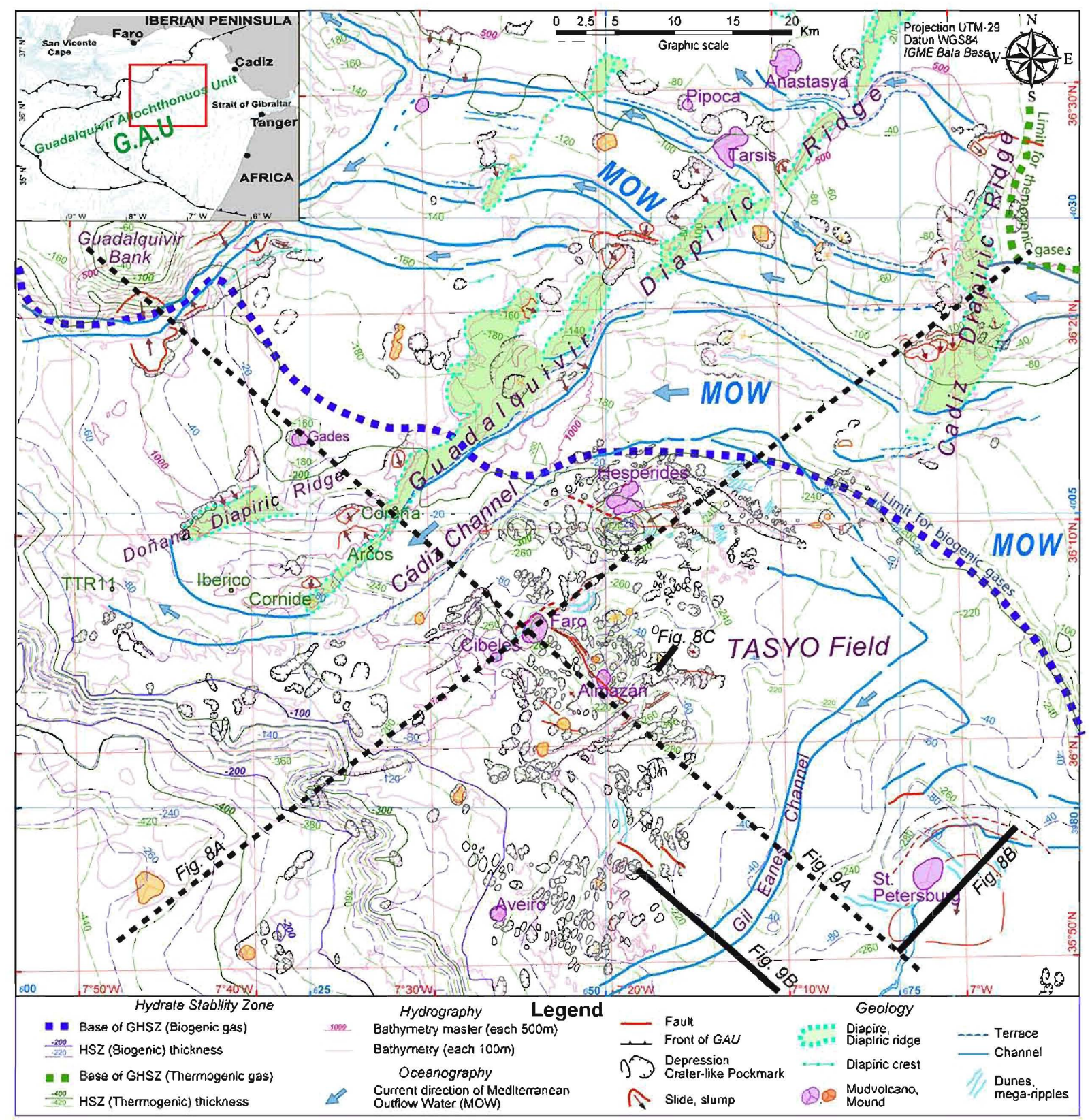

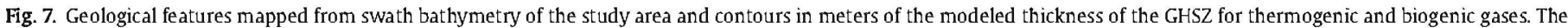
thick dotted line marks the upper boundary of the biogenic GHSZ. Thinner straight lines indicate the location of synthetic profiles of the GIS model.

channel, the main pathway of the Mediterranean outflow undercurrent, and other minor channels, such as the Gil Eanes channel, that dissect the Tasyo field. A detailed description of the contouritic channel system can be found in Hernández-Molina et al. (2003). The selected area is rich in mud volcanoes and mud carbonate ridges, and the Tasyo field is a zone especially affected by crater-like collapses, slide scars and mud volcanoes (e.g. Hespérides, Faro, Cibeles, Almazan, Aveiro, St. Petersburg, Fig. 7).

\subsection{Calculated BSR for thermogenic and biogenic sourced gases}

Two synthetic 2D profiles were derived from the 3D numerical surfaces of the predictive model following: (i) a SW-NE orientation from the Cadiz shelf to the middle continental slope crossing the Cadiz channel and the Tasyo field (Fig. 8A); and (ii) a NE-SW orientation from the Algarve shelf to the Tasyo field crossing the
Algarve basin, the Guadalquivir Bank, the Guadalquivir Diapiric Ridge and the Cadiz Channel (Fig. 9A). These profiles depict the theoretical BSRs for thermogenic and biogenic gases, in relation to the swath bathymetry, bottom seawater temperatures and geothermal gradients, because one of the aims of this task was to investigate the influence of anomalous geothermal gradients and warm undercurrents on the behavior of the hydrate stability zone. For this reason both profiles cross mud volcanoes with known values of heat flow and the seafloor warmed by the MOW undercurrent.

The calculated BSR for thermogenic gases reaches the upper continental slope at a water depth close to $450 \mathrm{~m}$, even in the areas of seafloor affected by the MOW (Figs. $6 \mathrm{C}$ and 9A). In contrast, the uppermost limit for the biogenic BSR is located at water depths of about $800 \mathrm{~m}$ (Figs. 6D and 9A). Therefore, under the present oceanographic conditions, the only hydrates stable at water depths 


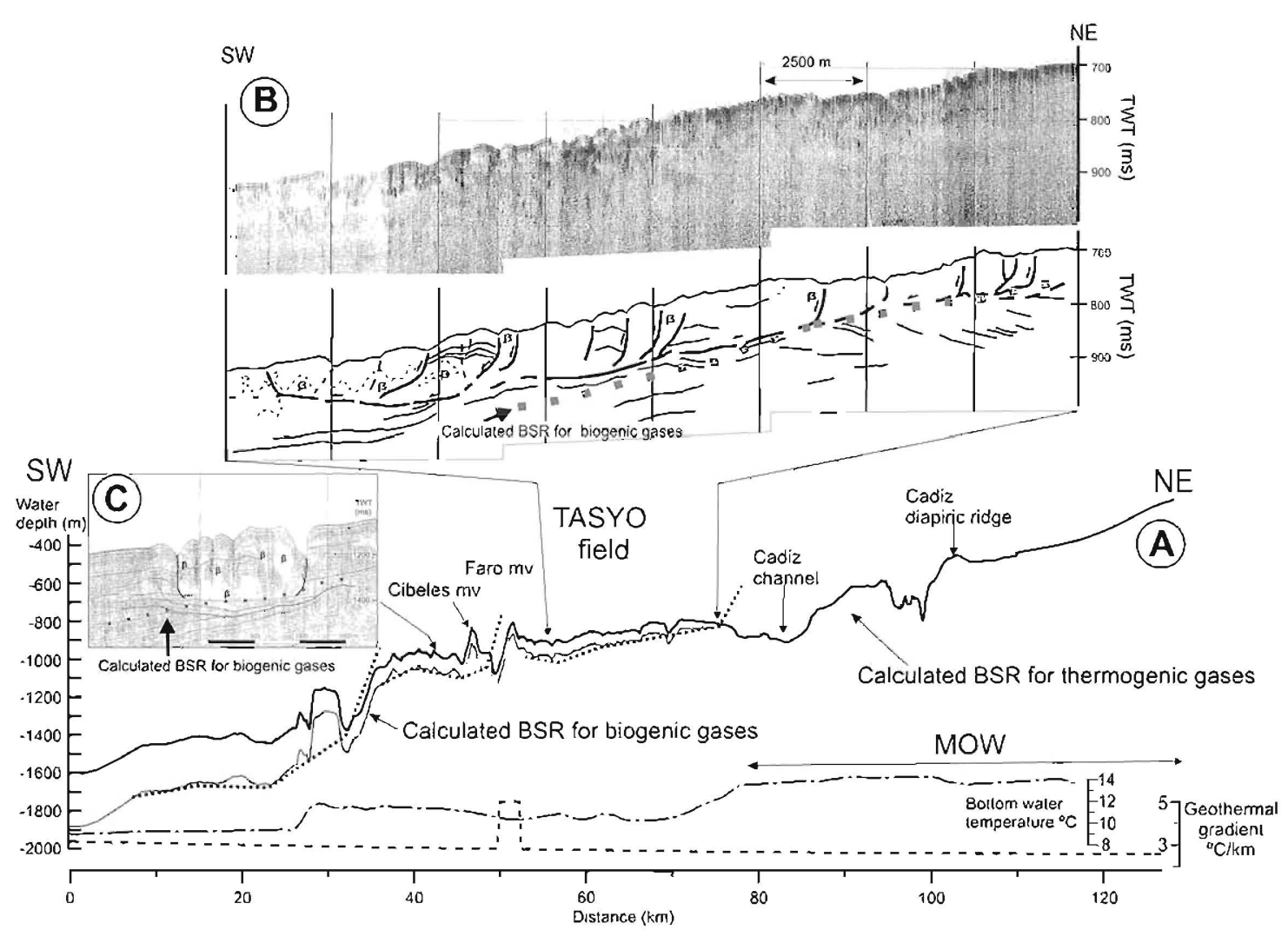

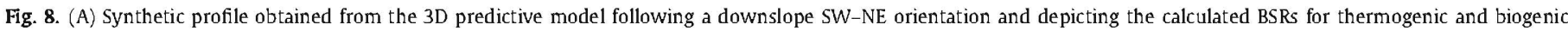

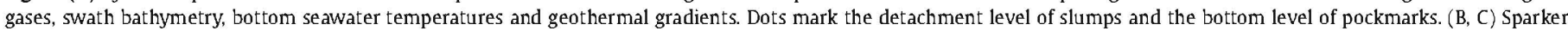

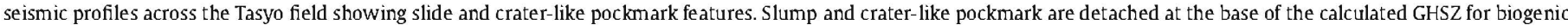
gases. " $\beta$ " are seismic blanking facies. Profile orientations are indicated in Fig. 7. See text for further explanation.

of between $450 \mathrm{~m}$ and $800 \mathrm{~m}$ are those derived from thermogenic gases (Figs. 6C,D). BSR-like reflections have been reported in this area at $340 \mathrm{~m}$ water depth and about $80 \mathrm{~ms}$ TWT deep in the sediment column related to diapiric ridges (Somoza et al., 2000; Casas et al., 2003). Evidence of BSR-like features inside shallow mud volcanoes have also been reported on the Moroccan margin, at water depths of around $350 \mathrm{~m}$ (Depreiter et al., 2005). Following our model, the occurrence of these geophysically-detected BSRs on the upper slope associated with mud volcanoes or diapiric ridges must be related to focused fluid flow of thermogenic-type gases in seafloors influenced by Mediterranean or Atlantic waters. In contrast, the hydrate stability field will be placed deeper (800$900 \mathrm{~m}$ ) in more mature edifices where thermogenic and biogenic gases become more mixed, as reported by Stadnitskaia et al. (2006). According to this, the only hydrates sampled in the Gulf of Cadiz at water depths of $900 \mathrm{~m}$ or deeper are associated with mature mud volcanoes such as Ginsburg (Kenyon et al., 2000; Kopf et al., 2004), Bonjardim (Kenyon et al., 2001; Kopf et al., 2004) and Captain Arutyunov (Ivanov et al., 2003; Kopf et al., 2004) (Fig. 1).

\section{Uncertainty assessment and sensitivity analysis}

In order to evaluate the degree of reliability in the interpretation of the results of the proposed model, an uncertainty assessment and sensitivity analysis study has been carried out of input errors from geospatial data and the resulting prediction uncertainty of the 3D proposed model has been established.

We have established two scopes in the study of the error assessment of the proposed model: (a) source errors in the building of the digital 3D surfaces of temperature, bathymetry and geothermal gradient; and (b) sensitivity analysis through map algebra analysis for calculation of the GHSZ thickness.

5.1. Uncertainty assessment in the inferred 3D surfaces (bathymetry, seafloor temperature and geothermal gradient)

\subsubsection{Uncertainty assessment in the building of DBM}

Bathymetric surface error assessment has been developed by different methods both SBDM and EDBM.

Raw data of SBDM were separated $18 \mathrm{~m}$ in mean with a few artifacts of erroneous data of difficult filtering in the post-processing phase. For smoothing SBDM, we have calculated the median statistic value in a grid of $50 \mathrm{~m}$ of cell size. Error assessment of SBDM has been calculated by the standard deviation of the values of depth in the same of above mentioned mesh (Fig. 10A). Error assessment in SBDM evidences two types of errors. First type ("a" in Fig. 10A) comes from a wrong record of the XBT sounder (wrong profile of sound velocity through the water column), and generates a systematic biased error in depth along the track of the vessel, exaggerated in the external beams of the ecosounder. The second type of error ("b" in Fig 10A) is produced on the steep slopes of the study area, more precisely on the flanks of the submarine canyons and dipairic ridges, In this places, uncertainty is greater due to a greater number of anomalous refractions and reflexions produced by bottom steep slopes.

Uncertainty in EDBM has been difficult to obtain due to the complex and diverse nature of the data source. As EDBM has been conceived as a browse to the bathymetric database available, uncertainty of EDBM is depending of the uncertainty knowledge linked to bathymetric features stored in the database. 

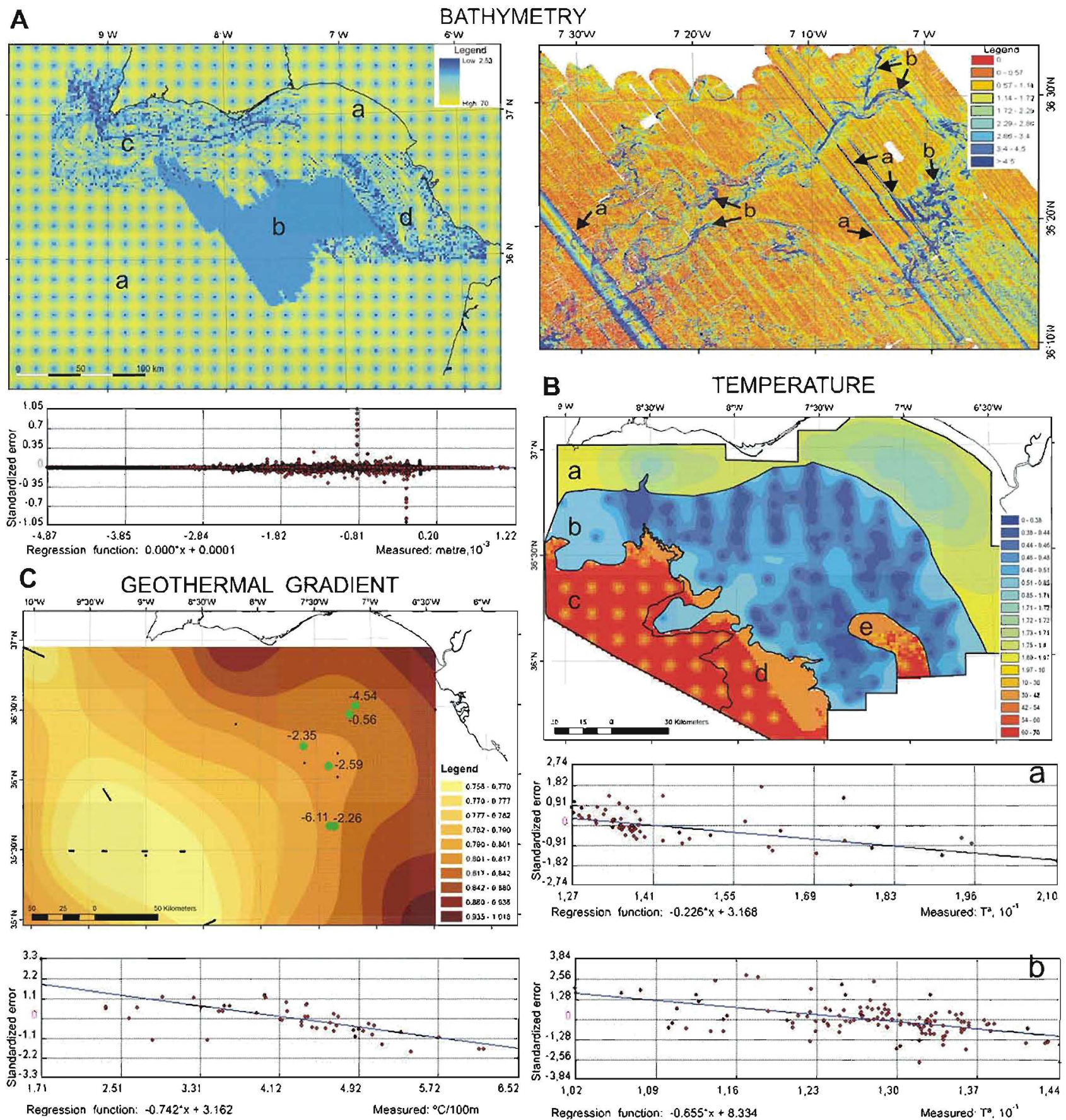

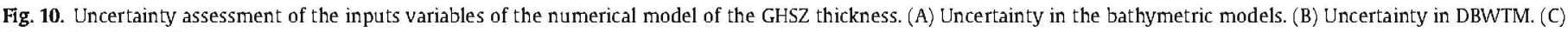
Uncertainty in DGGM.

variation inside each water masses is low, the tongue of NACW surrounded by MOW seems to suggest an instability, on at least a seasonal-to-annual scale, in the circulation of the MOW undercurrent. This unstability carried out an uncertainty from $\pm 2{ }^{\circ} \mathrm{C}$ to $\pm 4^{\circ} \mathrm{C}$. Implications of this temperature uncertainty in the proposed model and the relationship with the geological structures found in this area will be discussed in the bullet 6.1 .

5.1.2.2. Uncertainty assessment in the mosaicking 3D surface. Uncertainty assessment in DBWTM (Fig. 10B) has been conceived as a mosaic of each seafloor areas affected for the different water masses (the same method we used in the building of DBWTM). In the northern area affected by NASW-NACW ("a" in Fig. 10B) and the area affected by MOW ("b" in Fig. 10B), uncertainty has been assessed by the standard error of the stochastic inference. In the areas affected by the tongue of NASW (" $e$ " in Fig. 10B), NADW ("c" in Fig. 10B) and the transitional area between MOW and NADW ("d" in Fig. 10B), we have applied the uncertainty of EDBM due to seafloor temperature in these areas is a reclassification of EDBM.

As it might be expected, uncertainty in DBWTM (Fig. 10B) presents two areas clearly differentiated. The first corresponds with the areas inferred from CTB-XBT data. Here, uncertainty is controlled by the sounder distribution. Uncertainty is higher in the external zones and lower in central zones where there is a high 
density of samples. The second corresponds with the part of DBWTM reclassified from EDBM. Here, uncertainty is independent of the distribution of the CTD-XBT sounders because it is inheritance of EDBM. Although here uncertainty is highest, results must be taken with caution as it has been exposed in bullet 5.1.1. Finally, the strong contrast of uncertainty observed in the boundary of each seafloor area affected by the different water masses, is related to the fact that it has been inferred independently. Nevertheless, this works as independent thermodynamic systems as has been observed on the bathythermographic profiles (CTD-XBT data), and it has been the base of the expert opinion for the DBWTM building.

\subsubsection{Uncertainty assessment in the building of DGGM}

Uncertainty in DGGM has been studied in two realms: (a) uncertainty assessment in the inference of RGTS; and (b) uncertainty assessment in the inclusion of geothermal anomalies of the mud volcanoes. Uncertainty assessment in RGTS has been assessed from standard error derived of the stochastic inference (Fig. 10C). RGTS uncertainty is lower in the southwest of the inferred area (about 0.76 ) where there is a high density of records. On the other hand, in the northeast area where only one record of geothermal gradient takes place, uncertainty is bigger but remains below of 0.85 .

In the uncertainty assessment for the inclusion of geothermal anomalies of the mud volcanoes, we have followed the same methodology (expert opinion) as the DGGM building. First step, a cross-validation between RGTS and the geothermal anomalies recorded in the mud volcanoes has been done in order to assess the maximum error that will be produced by not taking anomalies into account (Fig. 10C). Finally, uncertainty obtained in the cross-validation has been included into RGTS-error model with an area equal to the mud volcano.

\subsection{Sensitivity analysis}

The aim of this sensitivity analysis is better to understand the structure and behavior of the predictive 3D model, and establish which variables are independent and which are correlated (their behavior depends on the behavior of others). A detailed study of the sensitivity in order to evaluate the error and thrust of the model is not in the scope of this paper, but will be the aim of a future paper dedicated only to this topic.

In order to understand the behavior of the model to input variations, a local and static sensitivity analysis (Fig. 11) has been carried out in two points ("D" in Fig. 6). The two points are located over seafloor inside GHSZ, in different areas. Point $\alpha\left(36^{\circ} 13.6^{\prime} \mathrm{N}, 7^{\circ}\right.$ $33.7^{\prime} \mathrm{W}$ ) are located over an area of the critical equilibrium where GHSZ thickness are thinned by the influence of the MOW. Point $\beta\left(35^{\circ} 59.9^{\prime} \mathrm{N}, 8^{\circ} 16.36^{\prime} \mathrm{W}\right)$ are located over a cold and stable area influenced by the NADW. Predictive 3D model has been run in these points varying the parameters (depth, bottom seawater temperature and geothermal gradient) a $1 \%, 5 \%, 10 \%$ and $20 \%$ of their range of values. The range of values of bottom seawater temperature varies from $6.9^{\circ} \mathrm{C}$ (NADW) to $21.1^{\circ} \mathrm{C}$ (NASW). The range of values of depth is $800 \mathrm{~m}$ which is the greater GHSZ thickness calculated by the model. Two situations have been established in order to evaluate the effect of not taking into account the anomalies of the geothermal gradient measured in mud volcanoes: (a) taking into account only the global trending of the geothermal gradient (from $2.4^{\circ} \mathrm{C} / 100 \mathrm{~m}$ to $4{ }^{\circ} \mathrm{C} / 100 \mathrm{~m}$ ); and (b) taking into account the anomalies of the mud volcanoes (from $2.4{ }^{\circ} \mathrm{C} / 100 \mathrm{~m}$ to $8{ }^{\circ} \mathrm{C} / 100 \mathrm{~m}$ ). Result of this iterative process has been compared with the presented 3D model, to establish the behavior of the variables through the model (Fig. 11).

Sensitivity analysis shows that the presented 3D model is most sensible to bottom seawater temperature oscillation. Oscillations of $2.84{ }^{\circ} \mathrm{C}(20 \%$ of the range of values in the study area $)$ give a maximum

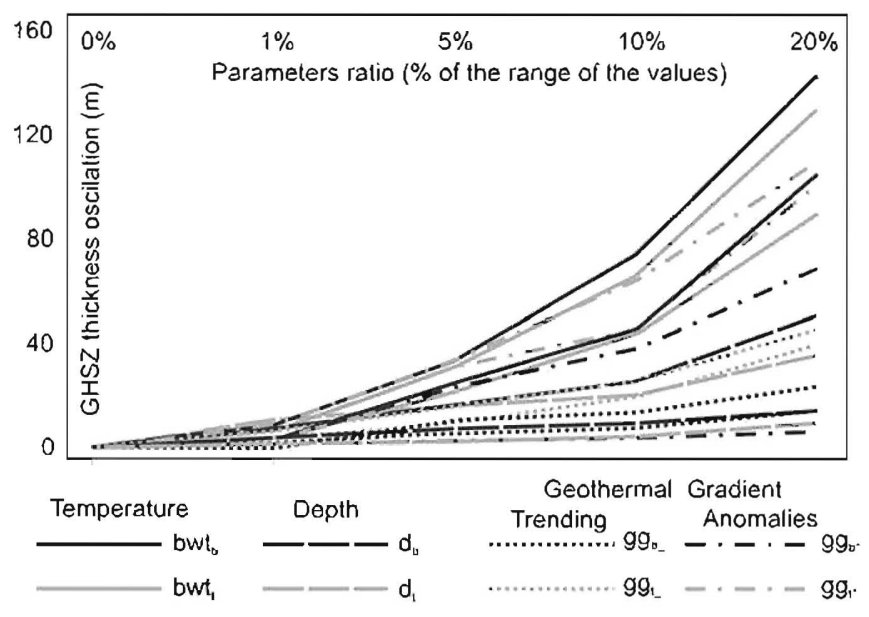

Fig. 11. Sensitivity analysis of the predictive 3D model. Diagram shows the sensitivity of the model to their parameters: temperature, depth and geothermal gradient. Parameters have been modified $1 \%, 5 \%, 10 \%$ and $20 \%$ in order to calculate the GHSZ thickness oscillation. bwt $t_{b}$, sensitivity of the model (for biogenic gases) versus bottom seawater temperature. bwt $_{\mathbf{t}}$, sensitivity of the model (for thermogenic gases) versus bottom seawater temperature. $\mathbf{d}_{\mathbf{b}}$, sensitivity of the model (for biogenic gases) versus depth. $\mathbf{d}_{\mathbf{t}}$, sensitivity of the model (for thermogenic gases) versus depth. $\mathbf{g g}_{\mathbf{b}}$, sensitivity of the model (for biogenic gases) versus the trending of the geothermal gradient.

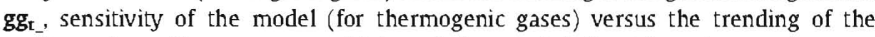
geothermal gradient. gg $_{\mathbf{b}}$ ', sensitivity of the model (for biogenic gases) versus geothermal gradient plus positive anomalies of mud-volcanoes. ggt $_{\mathbf{t}}$, sensitivity of the model (for thermogenic gases) versus geothermal gradient plus positive anomalies of mud-volcanoes.

oscillation of the GHSZ thickness of about $140 \mathrm{~m}$, with a clear behavior as additive independent variable. Besides, oscillations of $120 \mathrm{~m}$ in sea level (20\% of the range of values in the study area) such as those appearing in glacial conditions, give variations from $5 \mathrm{~m}$ to $50 \mathrm{~m}$ of the GHSZ thickness, with behavior as correlated variable. So, this analysis points that in glacial-interglacial situations, GHSZ thickness seems more sensible to seafloor undercurrent fluctuations or temperature changes than sea level oscillations.

Geothermal gradient behavior as correlated variable depending on the gas composition modeled. When GHSZ thickness is modeled for a biogenic gas taking into account only the global trending of the geothermal gradient, the model seems little sensible to the geothermal gradient. Besides, when GHSZ thickness is modeled for a thermogenic gas taking into account the anomalies of the geothermal gradient of the mud volcanoes, the model seems very sensible to the geothermal gradient and has behavior as an additive variable.

In the Gulf of Cadiz, evidences of thermogenic gases have been detected in mud volcanoes where very high geothermal gradients have been recorded. Nevertheless, in mud volcanoes with high thermal gradient values, such as Gades, we would have an uncertainty of about 96-100 m depending on taking into account or not, the geothermal gradient. If we fail to take into account anomalous geothermal gradients inside mud volcanoes (for a total of 20 mud volcanoes with a mean diameter of $2 \mathrm{~km}$ ) the total volume of the thermogenic GHSZ will increase by $810^{9} \mathrm{~m}^{3}$. For a total volume estimated in the Gulf of Cadiz of $10.0910^{15} \mathrm{~m}^{3}$, this assumption will mean an increase of $0.810^{-4} \%$ which, although insignificant, is an important input for calibrating the model.

\section{Discussion}

\subsection{Consequences of changes in seafloor temperatures on hydrate stability}

The upper limit of the calculated biogenic BSR rises under the warming influence of the MOW (Fig. 8A). This is the case in the 
Cadiz Channel, where an abrupt increase in seafloor temperatures up to $13-14{ }^{\circ} \mathrm{C}$ represents the upper boundary of the calculated biogenic BSR (Fig. 8A). Thus, calculated biogenic BSR begins only within Atlantic-type bottom seawater temperatures at around $10^{\circ} \mathrm{C}$ within the Tasyo field (Figs. 7 and $8 \mathrm{~A}$ ). In this field, where water depths range from $800 \mathrm{~m}$ to $1100 \mathrm{~m}$, the calculated biogenic GHSZ is very thin, reaching less than $50 \mathrm{~m}$ (Figs. $8 \mathrm{~A}$ and $9 \mathrm{~B}$ ). Seismic profiles and swath bathymetry in this area reveal numerous craterlike collapses, slumps and mud volcanoes. The observed basal boundaries that act as a detachment level for slumps (Fig. 8B) and collapses (Fig. 8C) coincide with the calculated base of the biogenic GHSZ (Fig. 8). Furthermore, the mounded transparent facies (" $\beta$ " in Figs. 8 and 9) observed between minor MoW channels (e.g. Gil Eanes) are rooted in undulating basal reflectors that match the calculated biogenic GHSZ (Fig. 9b). The occurrence of mass movements in the Tasyo field area is not explained by slope processes, because the measured mean slope $\left(1-2^{\circ}\right)$ never exceeds the angle of internal friction $\left(16^{\circ}\right)$ calculated for this area (Lee and Baraza, 1999). Therefore, it is suggested here that collapses and slides could well be related to a dissociation process at the base of the GHSZ, and are presumably triggered by seismogenetic activity. The occurrence of biogenic BSR in the Tasyo field can be explained, at least theoretically, but the absence of any regional biogenic BSR is more striking. One possibility might be that the flux of methane is insufficient to generate significant amounts of gas hydrate (Depreiter et al., 2005). Therefore, the proposed numerical model explains that this is a zone of fragile equilibrium for the hydrate stability field of methane, which is especially vulnerable to changes in sea level and/or bottom seawater temperature (Figs. 8 and 9). The presence of Atlantic water masses inside the MOW adds another instability factor in this zone of fragile equilibrium for the hydrate stability field. The maximum seasonal-to-annual uncertainty of $\pm 4{ }^{\circ} \mathrm{C}$ in the temperature records inside MOW represents an uncertainty of $\pm \mathbf{4 5} \mathrm{m}$ in the calculation of the GHSZ thickness. As the mean GHSZ thickness calculated in the seafloor area warmed by MOW is about $75-80 \mathrm{~m}$, this means that huge oscillation (more than half of its thickness) takes place in the base of the GHSZ over annual cycles in this zone of fragile equilibrium. In Fig. 6D, the effect of the tongue of NACW water makes the base of the biogenic GHSZ on the Spanish margin (900-950 m) deeper than it is on the Portuguese margin $(750-800 \mathrm{~m})$.

The huge oscillation of the base of the GHSZ below the seafloor warmed by the MOW could explain the formation of the pockmarks in the Tasyo Field, which is located over sandy submarine fans and lobes inside the hydrate stability field (Figs. 1 and 7). Sandy bodies laterally homogenize the storage of gas from isolated feeder channels. Changes in hydrate stability field conditions in this zone of fragile equilibrium could have caused a massive dissociation of the whole of this sandy hydrate-bearing body.

\subsection{Focused flow and anomalous heat flows in the hydrate stability} zone

Thermogenic gases occur mainly as focused flow along fault surfaces associated with seafloor structures such as mud volcanoes (Henry et al., 1996; Kopf, 2002). The calculated GHSZ for mud volcano structures shows a sharp decrease towards the crest, due to the influence of bathymetry and heat flow. All sediment heat probes deployed in mud volcanoes have reported anomalous values of heat flow. For example, the heat flow for the Almazan mud volcano (Tasyo field, Fig. 7) is $87.92 \mathrm{~mW} \mathrm{~m}^{-2}$, with conductivity values of $1.025 \mathrm{~W} \mathrm{~m}^{-1} \mathrm{~K}^{-1}$ (Gardner et al., 2001). The diameter of the volcano is $1.2 \mathrm{~km}$ and the summit of the cone rises $75 \mathrm{~m}$ above the bottom, reaching a water depth of $870 \mathrm{~m}$. The calculated base of the biogenic GHSZ rises from $75 \mathrm{mbsf}$ at the base to $58 \mathrm{mbsf}$ at the cone top (Fig. 8A). The base of the GHSZ of thermogenic gases also shifts upwards from $250 \mathrm{mbsf}$ at the base to $160 \mathrm{mbsf}$ at the top.

The decrease in depth of the base of the GHSZ towards the crest of the mud volcanoes is still more evident in areas influenced by the MOW. This is the case of the Gades mud volcano, located at a water depth of $915 \mathrm{~m}$ under the influence of the Mediterranean undercurrent (Fig. 7), where Gardner et al. (2001) measured anomalous heat values of $49.67 \mathrm{~mW} \mathrm{~m}^{-2}$ with conductivity values of $0.977 \mathrm{~W}$ $\mathrm{m}^{-1} \mathrm{~K}^{-1}$. The base of the calculated biogenic GHSZ lies only $10 \mathrm{mbsf}$ at the cone top, and the thermogenic GHSZ is located at $160 \mathrm{mbsf}$ but deepens to 200 mbsf towards the outer edifice (Fig. 9A). The shape of the modeled BSR coincides with the geophysically interpreted BSR below mud volcanoes on the Moroccan margin (Depreiter et al., 2005). According to the proposed numerical model, the GHSZ is thicker in localities with thermogenic production than those with biogenic production, such as mud volcanoes, even in areas with high heat flow.

\subsection{Comparative with previous models and proposed model contributions}

Several GHSZ 3D models have been published using gridded datasets and applying transient models: Gulf of Mexico (Milkov et al., 2000), Norwegian margin (Mienert et al., 2005), Chinese Sea (Wang et al., 2006), Congo continental slope (Sultan et al., 2004), European margin (Miles, 1995) and the Indian continental margin (Rao, 1999). All of them do important generalizations and assumptions in the physical parameters ( $T$ - temperature, $D$ - depth, $G$ geothermal gradient) to simplify calculus if spatial variability of $T$ $D-G$ parameters will be taken into account. Generalizations and assumptions are made in order to calculate the bottom seawater temperature as a function of depth (Miles et al., 1995; Milkov et al., 2000; Wang et al., 2006), apply a constant geothermal gradient for the total of the studied area (Milkov et al., 2000; Wang et al., 2006), or deduce a geothermal gradient value from burial depth of BSR (De Batist et al., 2002). Most of these previous models take into account the parameters controlling the GHSZ thickness as static geographical variables, implying a difficulty of not easy solution the incorporation of new data in real time, to add or simulate geographical variations of $T-D-G$ parameters, to include or modify limits to force interpolations, to assess the uncertainty of the model and propagation error of the gridded datasets. It is especially important in areas with warm underwater currents (that decrease greatly GHSZ thickness) and fluid flow (with anomalous values of the geothermal gradient) such as Gulf of Mexico or Gulf of Cadiz. Proposed model is profiting from GIS environment managing the gridded datasets of $T-D-G$ parameters as dynamic geographical variables. New data are added inside proposed model updating or adding records of its database, improving the model through a better understanding of the environment. For example: new multibeam data implies to increase a record in the table of feed the TIN of build EDBM; the inclusion or modification of the track of an underwater current, involves to update the vectorial dataset which establish the limits of interpolation of the bottom seawater temperature; or a new geothermal gradient anomalies entail to adding a new geographical features in the anomalies gridded dataset.

The European model of the GHSZ thickness published by Miles (1995), that takes into account geological and oceanographical parameters as static variables, seems to show a huge dependence or sensitivity to the depth in the Gulf of Cadiz. Besides, the proposed model shows that GHSZ thickness is quite sensitive to the changes in temperature induced by MOW. Miles (1995) theorizes presence of hydrates from just the lower slope of the Gulf of Cadiz, whereas in the proposed model hydrates could be present at the base of the upper slope. 
Besides, GIS environment allows the possibility to include work processes focused to the uncertainty assessment and the error propagation included in the gridded datasets involved in map algebra analysis, and analyzes the weakness of the model. This is an added value of the GIS environment and a contribution of the proposed model not taken into account in the previous models.

\section{Conclusions}

The proposed numerical model described herein allows the incorporation of real 3D data such as bottom seawater temperatures determined by conductivity-temperature-depth (CTD) measurements, swath bathymetry, sub-seafloor gradients measured with sediment heat probes, and functions obtained from hydrocarbon compositions of sediment and hydrate samples. Furthermore, the thickness of the GHSZ has been calculated through an algorithm involving the regional oceanographic variables converted to 3D surfaces (depth-pressure, geothermal gradient and bottom seawater temperature) and the hydrate equilibrium condition functions. The behavior of the hydrate stability field follows a logarithmical function whose solution with the geothermal gradient function is a transcendent function $(y=\ln y)$, without a real solution, that we have named the "transcendent function of the base of the GHSZ". The easiest GIS method for solving is to increase the unknown on one side of the equation iteratively by means of a loop until the equation is balanced.

The proposed numerical model depicts the distribution of GHSZ thickness and the theoretical BSRs for distinct gas sources under the present prevailing oceanographic conditions in the Gulf of Cadiz. Gas composition and bottom seawater temperatures are two important factors controlling the thickness of the GHSZ and the occurrence of BSR. Thus, the upper boundary of GHSZ for thermogenic-type gases reaches the upper continental slope at water depths $(450 \mathrm{~m})$ shallower than the GHSZ for biogenic-type gases $(770 \mathrm{~m})$. Therefore, under the present oceanographic conditions, only the hydrates fuelled from deep-seated thermogenic gases are stable on the upper continental slope. The thickness of the calculated GHSZ of both types of hydrocarbon gases decreases dramatically just beneath the seafloor affected by MOW undercurrent warming. The upper boundary of the biogenic GHSZ is strongly controlled by the MOW undercurrent, represents a zone of fragile equilibrium for methane hydrate stability, and is particularly vulnerable to sea level changes and/or oscillations of bottom seawater temperature.

Predictive model show a high sensitivity to the bottom seawater temperature with a behavior as additive and independent variable. Besides, the model is little sensitive to sea level changes. Finally, geothermal gradient behavior is as correlated variable very dependent of gas composition.

\section{Acknowledgments}

We are grateful to all participants in the Tasyo and Anastasya research cruises: the captains, technicians and crews of R/V Cornide de Saavedra and R/V Hesperides. Special thanks are due to the projects Cadisar (UMR CNRS 5805, France), Gap (Germany) and Golfo (SMAR99-0643T, Spain) for contributing oceanographic data to this study. We are especially grateful to Michael Ivanov and Luis Pinheiro for their helpful co-operation within the framework of the TTR IOC/ UNESCO Programme. Thanks are extended to Repsol-Ypf for their helpful collaboration. This work is part of the ESF Euromargins projects Mvseis (O1-LEC-EMA24F, REN2002-11669-E-MAR) and Moundforce (O1-LEC-EMA06F, REN2002-11668-E-MAR), and
Consolider-Ingenio 2010 CSD2006-0041-“Topolberia”. CJD is a member of UCM Research Group 910198 and CGL2005-01336/BTE.

\section{References}

Andreassen, K., Hart, P.E., Grantz, A., 1995. Seismic studies of a bottom simulating reflector related to gas hydrate beneath a continental margin of the Beaufort Sea. J. Geophys. Res. 100, 12659-12673.

Bagirov, E., Lerche, I., 1998. Flame hazards in the South Caspian Basin. Ener. Explor Exploit 16, 373-397.

Baraza, J., Ercilla, G., 1996. Gas-charged sediments and large pockmark-like features on the Gulf of Cadiz slope (SW Spain). Mar. Petrol. Geol. 13, 253-261.

Blinova, V., Stadnitskaia, A., 2001. Composition and origin of hydrocarbon gases from the Gulf of Cádiz mud Volcanic area. IOC Workshop Rep 175, 45-46.

Bonnin, J., Olivet, J.L., Auzende, J.M., 1975. Structure en nappe a l'ouest de Gibraltar. C.R Acad. Sci 280 (5), 559-562.

Bouriak, S., Vanneste, M., Saoutkine, A., 2000. Inferred gas hydrates and clay diapirs near the Storegga Slide on the southern edge of the Vøring Plateau, offshore Norway. Mar. Geol. 163, 124-148.

Campbell, K.J., 1991. Deepwater geohazards: an engineering challenge. Offshore 51 (10), 46-51. 60

Caralp, M.H., 1988. Late glacial to recent deep-sea benthic foraminifera from the northeastern Atlantic (Cadiz Gulf) and western Mediterranean (Alboran Sea): paleoceanographic results. Mar. Micropaleontol 13, 265-289.

Casas, D., Ercilla, G., Baraza, J., 2003. Acoustic evidences of gas in the continenta slope sediments of the Gula of Cadiz (E Atlantic). Geo-Mar. Lett 23, 300-310.

Claypool, G.E., Kaplan, I.R, 1974. The origin and distribution of methane in marine sediments. Mar. Sci. Plenum 3 (1331), 99-139.

Davie, M.K, Buffett, B.A., 2001. A numerical model for the formation of gas hydrate below the seafloor. J. Geophys. Res. 106 (B1), 497-514.

Davie, M.K., Buffett, B.A., 2003. A steady state model for marine hydrate formation: constraints on methane supply from pore water sulfate profiles. J. Geophys. Res. 108 (B10), 2495.

De Batist, M., Klerkx, J., Van Rensbergen, P., Vanneste, M., Poort, J., Golmshtok, A., Kremlev, A., Khlystov, O., Krinitsky, P., 2002. Active hydrate destabilization in Lake Baikal, Siberia? Terra Nova 14 (6), 436-442.

Depreiter, D., Poort, J., Van Rensbergen, P., Henriet, J., 2005. Geophysical evidence of gas hydrates in shallow submarine mud volcanoes on the Moroccan margin. J. Geophys. Res. 110, B10103, doi:10.1029/2005JB003622.

Dewey, J.F., Helman, M.L, Turco, E., Hutton, D.H.W., Knott, S.D., 1989. Kinematics of the western Mediterranean: alpine tectonics. In: Coward, M. (Ed.), Special Publication Geological Society of London, London, vol. 45, pp. 265-283.

Díaz-del-Río, V., Somoza, L., Martínez-Frías, J., Mata, P., Delgado, A., HernándezMolina, F.J., Lunar, R, Martín-Rubí, J.A., Maestro, A., Fernández-Puga, M.C. León, R, Llave, E., Medialdea, T., Vázquez, T., Hernández-Molina, F.J., 2003. Vast fields of hydrocarbon-derived carbonate chimneys related to the accretionary wedge/olistostrome of the Gulf of Cádiz. Mar. Geol. 195, 177-200.

Dickens, G.R., 2001. Modeling the global carbon cycle with a gas hydrate capacitor: significance for the latest Paleocene thermal maximum. In: Paull, CK. Dillon, W.P. (Eds.), Natural Gas Hydrates: Occurrence, Distribution and Dynamics. AGU Monograph Series 124, pp. 19-38.

Fehn, U., Snyder, G.T., Matsumoto, R., Muramatsu, Y., Tomaru, H., 2003. Lodine dating of pore waters associated with gas hydrates in the Nankai area. Japan. Geology 31, 521-524.

Fernández-Puga, M.C, 2004. Diapirismo y estructuras de expulsión de gases hidrocarburos en el talud continental del Golfo de Cádiz. PhD Thesis. Universidad de Cádiz, $336 \mathrm{pp}$.

Gardner, J.M., 2001. Mud volcanoes revealed and sampled on the Western Moroccan continental margin. Geophys. Res. Lett 28, 339-342.

Gardner JM, Vogt PR, Somoza L, 2001. The possible affect of the Mediterranean outflow water (MOW) on gas hydrate dissociation in the Gulf of Cadiz. EOS Transactions AGU, 82(47), Fall. Meet Suppl. Abstracts OS12B-0418.

Gascard, J.C., Richez, C., 1985. Water masses and circulation in the Western Alboran Sea and in the Straits of Gibraltar. Prog. Oceanogr 15, 157-216.

GEBCO, 2003. GEBCO, 2003 Centenary edition of the GEBCO digital atlas. Published on CD-ROM on behalf of the Intergovernmental Oceanographic Commission and the International Hydrographic Organization as part of the General Bathymetric Chart of the Oceans. CD ROM 551.462.2 GEB.35 2003.

Grevemeyer, I., Kaul, N., Gutscher, M.A., 2004. The thermal structure of the Gibraltar subduction zone from new heat flow measurements and finite-element modeling. Geophys. Res. Abstr 6, 02668.

101/B9 Henry, P., Le Pichon, X., Lallemant, S., Lance, S., Martin, J.B., Foucher, J.-P. Fiala-Médioni, A., Rostek, F., Guilhaumou, N., Pranal, V., Castrec, M., 1996. Fluid flow in and around a mud volcano field seaward of the Barbados accretionary wedge: results from Manon cruise. J. Geophys. Res., 20297-20323.

Hernández-Molina, F.J., Llave, E., Somoza, L, Fernández-Puga, M.C., Maestro, A., León, R. Medialdea, T., Barnolas, A., García, M., Díaz-del-Río, V., FernándezSalas, L.M., Vázquez, J.T., Lobo, F.J., Alveirinho-Dias, J.A., Rodero, J., Gardner, J. 2003. Looking for clues to paleoceanographic imprints: a diagnosis of the Gulf of Cadiz contourite depositional systems. Geology 31 (1), 19-22.

Hovland, M., Svensen, H., 2006. Submarine pingoes: indicators of shallow gas hydrates in a pockmark at Nyegga, Norwegian Sea. Marine Geology 228 (1-4), $15-23$ 
IGME, 1987. Contribución de la exploración petrolífera al conocimiento de la Geología de España. Instituto Geológico Minero de España, Madrid, 465 pp.

IGME, 2003. Mapa geológico de la plataforma continental española y zonas adyacentes. Memoria y Hoja $n^{\circ}$ 86-86S (Cádiz). Servicio de Publicacionesdel Ministerio de Ciencia y Tecnología. Instituto Geológico y Minero de España. Madrid. Escala 1:200.000.

Ivanov, M.K., Kenyon, N., Nielsen, T., Wheeler, A., Monteiro, H., Gradner, J. Comas, M., Akhmanov, A., Akhmetzhanov, G., 2000. Goals and principal results of the TTR-9 cruise. IOC/Unesco Workshop Rep 168, 3-4.

Ivanov, M.K., Kenyon, N.H., Nielsen, T., Pinheiro, L, Comas, M., Marani, M. Monteiro, J., Van Rensbergen, P., Furey, T., Henriet, J.P., Shipboard Scientific Party, 2003. Review of the principal results of the TTR-12 Cruise. UNESCO-IOC Workshop Rep 187, 3-5.

Ivanov, M., Westbrook, G.K., Blinova, V., Kozlova, E., Mazzini, A., Nouzé, H., Minshull, T.A., 2007. First sampling of gas hydrate from the Vøring Plateau. EOS 88 (19), 211.

Johnson, J., Stevens, I., 2000. A fine resolution model of the eastern North Atlantic between the Azores, the Canary Islands and the Gibraltar Strait. Deep-Sea Res I (47), 875-899.

Katz, D.L, Cornell, D., Kobayashi, R., Poettmann, F.H., Vary, J.A., Elenbaas, J.R. Weinaug, C.F., 1959. Handbook of Natural Gas Engineering. McGraw-Hill, New York, $802 \mathrm{pp}$.

Kenyon, N.H., Ivanov, M.K., Akhmetzhanov, A.M., Akhmanov, G.G., 2000. Multidisciplinary Study of Geological Processes on the North East Atlantic and Western Mediterranean Margins. (Preliminary Results of Geological and Geophysical Investigations During TTR-9 Cruise of R/V Professor Logachev, Jun-Jul, 1999) IOC Technical Series, vol. 56. UNESCO.

Kenyon, N.H., Ivanov, M.K, Akhmetzhanov, A.M., Akhmanov, G.G., 2001. Interdis ciplinary Approaches to Geoscience on the North East Atlantic and Mid-Atlantic Ridge. IOC Technical Series 60, UNESCO, 142 pp.

Kopf, A., 2002. Significance of mud volcanism. Rev. Geophys. 40 (2), 2-1, 2-26, doi: $10.1029 / 2000$ RG00093.

Kopf, A., Bannert, B., Brückmann, W., Dorschel, B., Foubert, A.T.G., Grevemeyer, I., Gutscher, M.-A., Hebbeln, D., Heesemann, B., Hensen, C., Kaul, N.E., Lutz, M. Magalhaes, V.H., Marquardt, M.J., Marti, A.V., Nass, K.S., Neubert, N., Niemann, H., Nuzzo, M., Poort, J.P.D., Rosiak, U.D., Sahling, H., Scheneider, J. Somoza, L., Thiebot, E., Wilkop, T.P., 2004. Report and preliminary results of Sonne cruise SO175. Miami-Bremerhaven, 12.11-30.12.2003. Berichte aus dem Fachbereich Geowissenschaften der Universität Bremen $228231 \mathrm{pp}$.

Kozlova, E., Gardner, J., Baudin, F., Largeau, C., 2000. Geochemical investigation of organic matter in rock clasts from mud volcano breccia (Gulf of Cadiz and Alboran sea). International Conference and Eighth Post-Cruise Meeting of the Training-Through-Research Programme. Granada, Spain. 31 January-3 February 2000, Geological Processes on European Continental Margins IOC Workshop Report 168, 16

Kvenvolden, K.A., 1988. Methane hydrate-a major reservoir of carbon in the shallow geosphere? Chem. Geol. 71, 41-51.

Kvenvolden, K.A., 1995. A review of the geochemistry of methane in natural gas hydrate. Org. Geochem 23, 997-1008.

Lacombe, H., Lizeray, J.C., 1959. Sur le régime des courants dans le Détroit de Gibraltar. C.R Acad. Sci. Paris 248, 2502-2504.

Lee, H., Baraza, J., 1999. Geotechnical characteristics and slope stability in the Gulf of Cadiz. Mar. Geol. 155, 173-190.

León, R., Somoza, L., Ivanov, M.K., Díaz-del-Río, V., Lobato, A., HernándezMolina, F.J., Fernández-Puga, M.C., Maestro, A., Medialdea, T., AlveirinhoDias, J.M., Vázquez, T., 2001. Seabed morphology and gas venting in the Gulf of Cadiz mudvolcano area: imagery of multibeam data and ultra-high resolution data. In: Akhmanov, G., Suzyumov, A. (Eds.), Geological Processes on Deepwater European Margins, vol. 175. IOC Workshop Report, pp. 43-45.

León, R, Somoza, L., Medialdea, T., Maestro, A., Díaz-del-Río, V., Fernández Puga, M.C., 2006. Classification of sea-floor features associated with methane seeps along the Gulf of Cádiz continental margin. Deep-Sea Res. Part II 53. 1464-1481.

Magalhães, V., Vasconcelos, C., Pinheiro, L., Gaspar, L., Ivanov, M., Díaz-del-Río, V. Somoza, L., Gadner, J., 2004. Methane related autigenic carbonates, chimneys and crust, from the Gulf of Cádiz. 32nd International geological congress. Florence (Italy), 2004. International Union of Geological Science (IUGS). In T18.01-Deep biosphere. CDROM.

Maldonado, A., Somoza, L., Pallarés, L., 1999. The Betic orogen and the IberianAfrican boundary in the Gulf of Cadiz: geological evolution (central North Atlantic). Mar. Geol. 155, 9-43.

Mata, M.P., Taberner, C., Julia, R., Teagle, D.A.H., Rejas, M., de Gibert, J.M., Alfonso, P. Perez-Outeiral, F., Díaz-del-Río, V., Somoza, L., 2005. Microbial-mediated carbonates in the Gulf of Cadiz: data of Iberico, Hesperides, Cornide and Fila de Hormigas (abstract of paper presented at the EGU General Assembly 2005 Vienna, Geophysical Research Abstracts, 7, EGU05-A-04528). (CDROM).

Mazurenko, L.L., Soloviev, V.A., Belenkaya, I., Ivanov, M.K., Pinheiro, L., 2002. Mud volcano gas hydrates in the Gulf of Cadiz. Terra Nova $14,321-329$

Mazurenko, L.L., Soloviev, V.A., Gardner, J.M., Ivanov, M.K, 2003. Gas hydrates in the Ginsburg and Yuma mud volcano sediments (Moroccan margin): results of chemical and isotopic studies of pore water. Mar. Geol. 195 (1-4), 201-210.

Medialdea, T., Vegas, R., Somoza, L., Vázquez, J.T., Maldonado, A., Díaz-del-Río, V. Maestro, A., Córdoba, D., Fernández-Puga, M.C., 2004. Structure and evolution of the "Olistostrome" complex of the Gibraltar Arc in the Gulf of Cadiz (eastern Central Atlantic): evidence from two long seismic cross-sections. Mar. Geol. 209 (1-4), 173-198.

Mienert, J., Posewang, J., Lukas, D., 2001. Changes in the hydrate stability zone on the Norwegian margin and their consequence for methane and carbon releases into the oceanosphere. In: Schäfer, P., Ritzrau, W., Schlüter, M., Thiede, J. (Eds.), The Northern North Atlantic: A Changing Environment, vol. 491. Springer Verlag, New York, pp. 281-290.

Mienert, J., Vanneste, M., Bünz, S., Andreassen, K., Haflidason, H., Sejrup, H.P., 2005. Ocean warming and gas hydrate stability on the mid-Norwegian margin at Storegga slide. Mar. Petrol. Geol. 22, 233-244.

Miles, P.R, 1995. Potential distribution of methane hydrate beneath the European continental margins. Geophys. Res. Lett. 22 (23), 3179-3182.

Milkov, A.V., Sassen, R, 2001. Estimate of gas hydrate resource, northwestern Gulf of Mexico continental slope. Mar. Geol. 179, 71-83.

Milkov, A.V., Sassen, R, Novikova I., Mikhailov, E., 2000. Gas hydrate at minimum stability water depths in the Gulf of Mexico: Significance to geohazard assessment Gulf Coast Assoc. Geol. Soc. Trans. L, 217-22A.

Miller, J.J., Lee, M.W., Von Huene, R, 1991. An analys is of a seismic reflection from the base of a gas hydrate zone, offshore Peru. AAPG Bull. 75 (5), 910-924.

Nelson, C.H., Baraza, J., Maldonado, A., Rodero, J., Escutia, C., Barber, J.H., 1999. Influence of the Atlantic inflow and Mediterranean outflow currents on Late Quaternary sedimentary facies of the Gulf of Cadiz continental margin. Mar. Geol. 155, 99-129.

Ochoa, J., Bray, N.A., 1991. Water mass exchange in the Gulf of Cadiz. Deep-Sea Res. 38 (1), S465-S503.

Pinheiro, L.M., Ivanov, M.K, Sautkin, A., Akhmanov, G., Magalhaes, V.H., Volkonskaya, A., Monteiro, J.H., Somoza, L., Gardner, J., Hamouni, N., Cunha, M.R., 2003. Mud volcanism in the Gulf of Cadiz: results from the TTR-10 cruise. Mar. Geol. 195, 131-151.

Rao, Y.H., 1999. C-program for the calculation of gas hydrate stability zone thickness. Comput Geosci 25, 705-707.

Serviços Geológicos de Portugal, 1992. Carta Geológica de Portugal a escala 1:500000. Serviços Geológicos de Portugal.

Sloan, E.D., 1998. Clathrate of Hydrates of Natural Gases, second ed. Dekker, New York, p. 641.

Somoza, L, Hernández-Molina, F.J., Vázquez, J.T., García-Garcia, A., Díaz del Río, V., 2000. El nivel de "BSR" en el talud superior del Golfo de Cadiz: implicaciones tecto-sedimentarias y paleoceanograficas. Congreso Geológico de España, Alicante, España.

Somoza, L., Gardner, J.M., Díaz-del-Río, V., Vázquez, J.T., Pinheiro, L.M., HernándezMolina, F.J., TASYO/ANASTASYA Shipboard Scientific Parties, 2002. Numerous methane gas-related sea floor structures identified in Gulf of Cadiz. EOS Trans. 83 (47), 541-547.

Somoza, L., Díaz-del-Río, V., León, R., Ivanov, M., Fernández-Puga, M.C., Gardner, J.M., Hernández-Molina, FJ., Pinheiro, L.M., Rodero, J., Lobato, A., Maestro, A., Vázquez, J.T., Medialdea, T., Fernández-Salas, L.M., 2003. Seabed morphology and hydrocarbon seepage in the Gulf of Cadiz mud volcano area: acoustic imagery, multibeam and ultra-high resolution seismic data. Sedimentary Processes and Seafloor Hydrocarbon Emission on Deep European Continental Margins. Mar. Geol. 195, 153-176.

Stadnitskaia, A., Ivanov, M., Gardner, J., 2000. Hydrocarbon gas composition and distribution in surface sediments of mud volcanic province, Gulf of Cadiz, NE Atlantic. VI International Conferenceon Gas in Marine Sediments. Abstract book. St. Petersburg, Russian, pp. 126-129.

Standnitskaia, A., Ivanov, M., van Weering, T.C.E., Sinninghe Damsté, J.S., Werne, J.P. Kreulen, R., Blinova, V., 2001. Molecular and isotopic characterization of hydrocarbon gas and organic matter from mud volcanoes of the Gulf of Cadiz, NE Atlantic. Final. Proc. Int Conf. Geological Processes on Deep-Water European Margins, Moscow, Russia. UNESCO IOC Workshop Report, 175: p. 47.

Stadniskaia, A., Ivanov, M., Blinova, V., Kreulen, R, Van Weering, T.C.E., 2006. Molecular and carbon isotopic variability of hydrocarbon gases from mud volcanoes in the Gulf of Cadiz, NE Atlantic. Mar. Petrol. Geol. 23, 281-296.

Sultan, N., Foucher, J.P., Cochonat, P., Tonnerre, T., Bourillet, J.F., Ondreas, H., Cauquil, E., Grauls, D., 2004. Dynamics of gas hydrate: case of the Congo continental slope. Mar. Geol. 206, 1-18.

Tréhu, A.M., Long, P.E., Torres, M.E., Bohrmann, G., Rack, F.R, Collett, T.S., Goldberg, D.S., Milkov, A.V., Riedel, M., Schultheiss, P., Bangs, N.L, Barr, S.R, Borowski, W.S., Claypool, G.E., Delwiche, M.E., Dickens, G.R., Gracia, E., Guerin, G., Holland, M., Johnson, J.E., Lee, Y.-J., Liu, C.-S., Su, X., Teichert, B., Tomaru, H., Vanneste, M., Watanabe, M., Weinberger, J.L., 2004. Three-dimensional distribution of gas hydrate beneath southern Hydrate Ridge: constraints from ODP Leg 204. Earth Planet. Sc. Lett. 222 (3-4), 845-862.

Van Rensbergen, P., Depreiter, D., Pannemans, B., Moerkerke, G., Van Rooij, D., Marsset, B., Akhmanov, G., Blinova, V., Ivanov, M., Rachidi, M., Magalhaes, V., Pinheiro, L., Henriet, J.-P., 2005. The El Arraiche mud volcano field at the Moroccan Atlantic slope, Gulf of Cadiz. Marine Geology 219, 1-17.

Vogt, P.R., Jung, W.-Y., 2002. Holocene mass wasting on upper non-Polar continental slopes-due to post-Glacial ocean warming and hydrate dissociation? Geophys. Res. Lett. 29 (9), 551-554.

Wang, S., Yan, W., Song, H., 2006. Mapping the thickness of the gas hydrate stability zone in the South China Sea. Terr. Atmos. Ocean. Sci. 17 (4), 815-828.

Wust, G., 1961. On the vertical circulation of the Mediterranean Sea. J. Geophys. Res. $66,3261-3271$ 